\title{
The Application of Display Room Lighting Concept in Wayang Museum
}

\author{
Marco Marco ${ }^{1}$ Eddy Supriyatna Marizar ${ }^{2 *}$ Maria Florencia $^{2}$ \\ ${ }^{1}$ Student of Interior Design Study Program, Faculty of Fine Arts and Design, Tarumanagara University, Jakarta \\ ${ }^{2}$ Lecturer of Interior Design Study Program, Faculty of Fine Arts and Design, Tarumanagara University, Jakarta \\ *Corresponding author.Email: eddysmarizar@yahoo.com
}

\begin{abstract}
Museum is a permanent institution that serves the community and is open to the public and is tasked with collecting, preserving, researching and exhibiting historical heritage in the form of objects and intangibles and their environment for educational, research and entertainment purposes. The current condition of the museum should be able to accommodate activities that can be done in the museum for the development of education, research and entertainment (Article 3 paragraph (2) of 2013 Government Regulation on Museums). Lighting is one of the most important physic aspects in the design of a building. The research method used is qualitative method. Begins with descriptive analysis and field observation. Descriptive method of analysis is a method that serves to describe the researched objects collected, processed, and produced conclusions (Sugiono:2009:29). The lighting of the display room in Museum Wayang has not been designed using the concept of lighting and meets the standard of lighting from SNI. Therefore, it is necessary to apply the concept of lighting consisting of; ambient lighting, focal glow, and play of brilliant. And it is necessary to select the right light source in order to maximize the display without damaging the show object. So that it produces the concept of proper lighting to overcome the problems in the Puppet Museum.
\end{abstract}

Keywords: display, museum, lighting, puppet

\section{INTRODUCTION}

Museum is a permanent institution that serves the public and is open to the public and is tasked with collecting, preserving, researching and exhibiting historical heritage in the form of objects and intangibles and their environment for educational, research and entertainment purposes (International Council of Museums, 1974). Wayang Museum is located at Jalan Pintu Besar Utara No.27 Pinangsia, RT.3/RW.6, Kota Tua, Kec. Taman Sari, West Jakarta, Special Capital Region of Jakarta 11110. The building was formerly the land of a church built in 1640 as de Oude Holandsche Kerk. In 1957 the building was handed over to the Indonesian Cultural Institute and on September 17, 1962 was given to the Ministry of Education and Culture of the Republic of Indonesia which was subsequently handed over to the Government of DKI Jakarta on June 23, 1968 to be used as a Puppet Museum.

The existence of the museum is very supportive of efforts to preserve cultural heritage created in the past in order to be maintained, so as to introduce and preserve the nation's cultural roots to the community. The current condition of the museum should be able to accommodate activities that can be done in the museum for the development of education, research and entertainment (Article 3 paragraph (2) of 2013 Government Regulation on Museums). Lighting is one of the most important physic aspects in the design of a building. In this journal, the author will focus the problem on lighting the display room at the Wayang Museum. Therefore, lighting analysis is needed to produce conclusions that are useful for the design of Wayang Museum.

\section{METHODS}

The type of research method chosen is a descriptive method of analysis and observation. Descriptive method analysis according to (Sugiono: 2009: 29) is a method that works to describe or give an overview of the object researched through data or samples collected, processed and come to a conclusion. The method of observation is observations of a case study or learning done deliberately, directed, sequentially, and according to the purpose. Recording on so called observation activities with observations. Result these observations are described with detail, precise, accurate, thorough, objective, and useful according to Prof. Heru. By method direct observation to Wayang Museum, found a problem main in the display space, that is lack of application of lighting concepts. The light source in the display room, the color temperature is inconsistent and there are several sources of light that have different intensities. And the display room has not applied 3 lighting concepts, which can 
add beauty to the interior of the Wayang Museum. The results of the descriptive method Wayang Museum analysis is describes the concept of lighting and some of the requirements needed in the lighting of the Wayang Museum display room

\section{RESULTS AND DISCUSSIONS}

\subsection{Field Observation}

In the existing condition of Wayang Museum lighting lacks a fairly good lighting design. Can be seen in figure 1 natural lighting on the display area that dominates the space in certain areas, resulting in a glare effect.

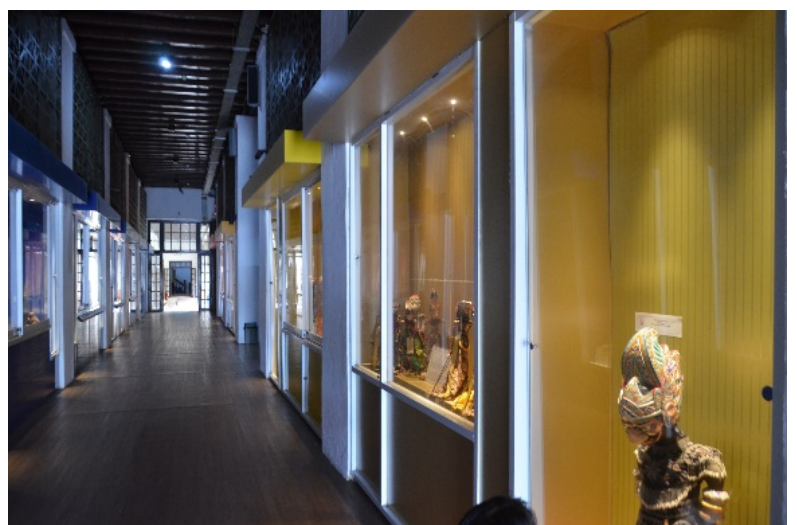

Figure 1 Display Room Lighting (Source: Writer)

While in figure 2, display room lighting in enclosed spaces is less plus artificial lighting sources in the room. In the shooting, additional lighting is needed in the form of flash for the object to be visible.

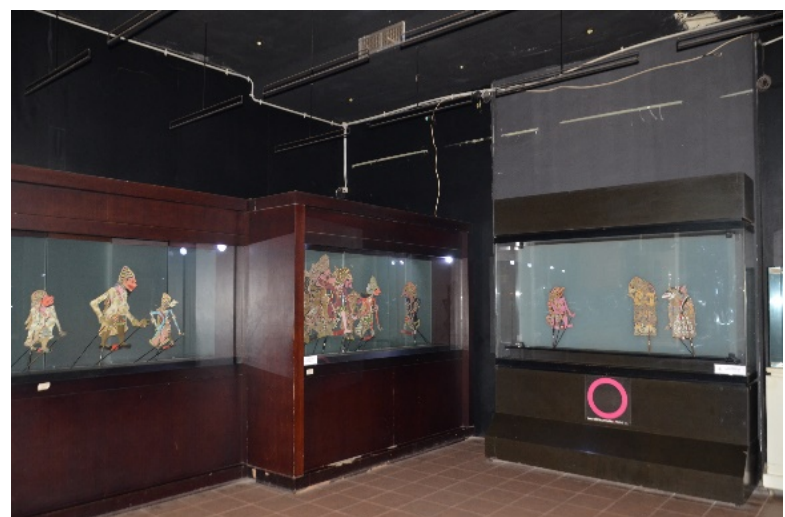

Figure 2 Poor lighting in enclosed Display Space (Source: Writer)

On the 2nd floor is an area that has been renovated and has got a fairly good lighting design design, because it has been thinking about aspects of the lighting concept in the display space.

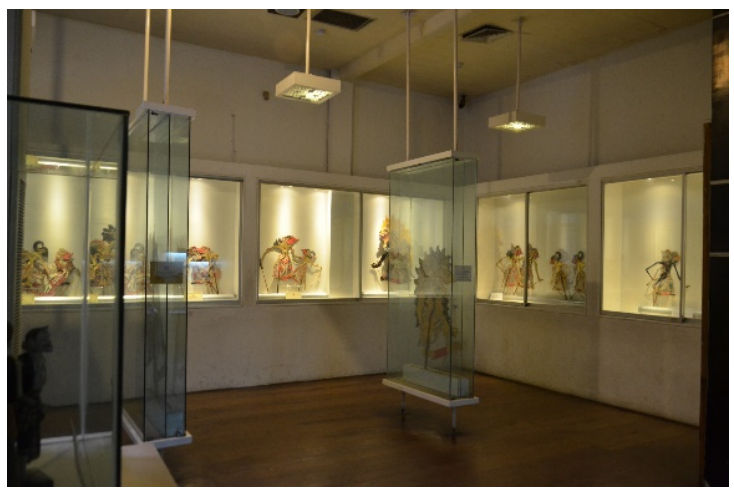

Figure 3 Display Room Lighting 2nd Floor

(Source: Writer)

In the display room on the second floor of the Wayang Museum, the concept of "play of brilliant" lighting has started. It can be seen in the lamp armature in the display room. The armature uses a decorative pattern that is square in shape and emits light that can be used as "focal glow" lighting.

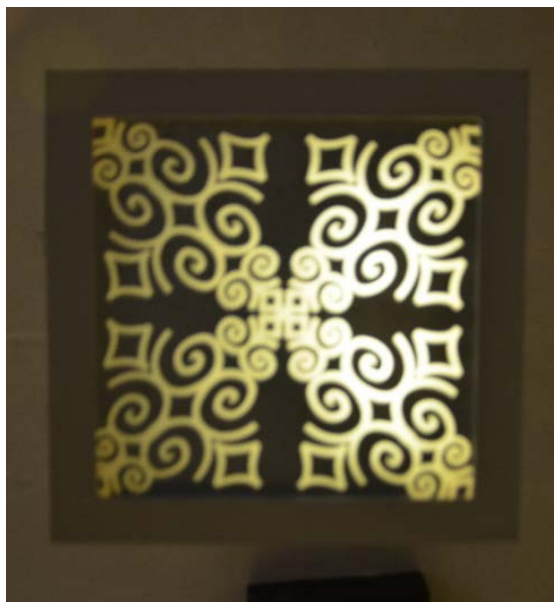

Figure 4 Unique armature using decorative patterns (Source: Writer)

The display room in Wayang Museum should get more attention, especially in lighting which is a means of sense of vision to show off the museum's exhibition objects. The display space should also be done evenly renovation (the whole room) to make the interior design look more integrated and more attractive.

\subsection{Lighting Standards}

Artificial lighting is better than natural lighting so as not to damage, artificial light must still be modified at a certain illumination (light level), to reduce ultraviolet radiation. In most museums, lighting fixtures in all exhibition areas and other collection areas must be UV-shielded to less than 75 microwatts per lumen and covered to prevent damage to objects in case of light damage. In general, based on the terms of illumination value issued by Illumination Engineers Society of North America (Lighting Handbook 
For General Use). In the exhibition area, the level of lighting is most dominant on the surface of the collectibles themselves. On the surface of the most significant objects, including objects from paper materials (such as prints and photos), the level of light should not exceed 5 Footcandles (Fc). Exhibition lighting needs will vary according to the type of exhibition, the size of the work, and the layout of each exhibition (Table 1). The goal may be to illuminate individual objects, not the entire space.

Table 1 Museum Room Light Level

\begin{tabular}{|c|c|c|}
\hline $\begin{array}{c}\text { ROOM } \\
\text { TYPES }\end{array}$ & MATERIAL & $\begin{array}{c}\text { LIGHTING } \\
\text { (FC) }\end{array}$ \\
\hline $\begin{array}{c}\text { Exhibition } \\
\text { (very sensitive) }\end{array}$ & $\begin{array}{c}\text { Paper objects, } \\
\text { prints, fabrics, } \\
\text { leather }\end{array}$ & $5-10$ \\
\hline $\begin{array}{c}\text { Exhibition } \\
\text { (sensitive) }\end{array}$ & $\begin{array}{c}\text { Oil painting, } \\
\text { temperament, } \\
\text { wood }\end{array}$ & $15-20$ \\
\hline $\begin{array}{c}\text { Exhibition (less } \\
\text { sensitive) }\end{array}$ & $\begin{array}{c}\text { Glass, stone, } \\
\text { ceramic, metal }\end{array}$ & $30-50$ \\
\hline $\begin{array}{c}\text { Storage of } \\
\text { collectibles }\end{array}$ & - & 5 \\
\hline $\begin{array}{c}\text { Handling of } \\
\text { collectibles }\end{array}$ & - & $20-50$ \\
\hline
\end{tabular}

There is also a standardization issued by the Indonesian National Standard (SNI) regarding lighting in showrooms. In figure 4 is described the standard level of lighting as well as the color temperature of lighting in the showroom.

Table 2 SNI Table of Showroom Lighting

\begin{tabular}{|c|c|c|c|c|c|}
\hline \multirow{2}{*}{$\begin{array}{c}\text { Room } \\
\text { Function }\end{array}$} & \multirow{2}{*}{$\begin{array}{c}\text { Lighting } \\
\text { Level }\end{array}$} & \multirow{2}{*}{$\begin{array}{c}\text { CRI } \\
\text { Group }\end{array}$} & \multicolumn{3}{|c|}{ Colour Temperature } \\
\hline & & & $\begin{array}{c}\begin{array}{c}\text { Warm } \\
\text { White } \\
<3300 \mathrm{~K}\end{array} \\
<\end{array}$ & $\begin{array}{c}\text { Cool } \\
\text { White } \\
3300 \mathrm{~K}- \\
5300 \mathrm{~K} \\
\end{array}$ & $\begin{array}{l}\begin{array}{l}\text { Daylight } \\
>5300 \mathrm{~K}\end{array} \\
>>\end{array}$ \\
\hline \multicolumn{6}{|c|}{ Shops and Showrooms/Gallery } \\
\hline $\begin{array}{l}\text { Showrooms } \\
\text { with large- } \\
\text { size object }\end{array}$ & 500 & 1 & + & + & + \\
\hline $\begin{array}{c}\text { Bakery and } \\
\text { Restaurant }\end{array}$ & 250 & 1 & + & + & \\
\hline Florist & 250 & 1 & & + & \\
\hline $\begin{array}{c}\text { Book and } \\
\text { Stationary } \\
\text { Shop }\end{array}$ & 300 & 1 & + & + & + \\
\hline Jewelry & 500 & 1 & + & + & \\
\hline $\begin{array}{l}\text { Leather and } \\
\text { Shoe Shop }\end{array}$ & 500 & 1 & + & + & \\
\hline $\begin{array}{l}\text { Clothing } \\
\text { Shop }\end{array}$ & 500 & 1 & + & + & \\
\hline Supermarket & 500 & 1 or 2 & + & + & \\
\hline Toy Shop & 500 & 1 & + & + & \\
\hline $\begin{array}{l}\text { Electronics } \\
\text { Shop }\end{array}$ & 250 & 1 or 2 & + & + & + \\
\hline $\begin{array}{l}\text { Music and } \\
\text { Sport Shop }\end{array}$ & 250 & 1 & + & + & + \\
\hline
\end{tabular}

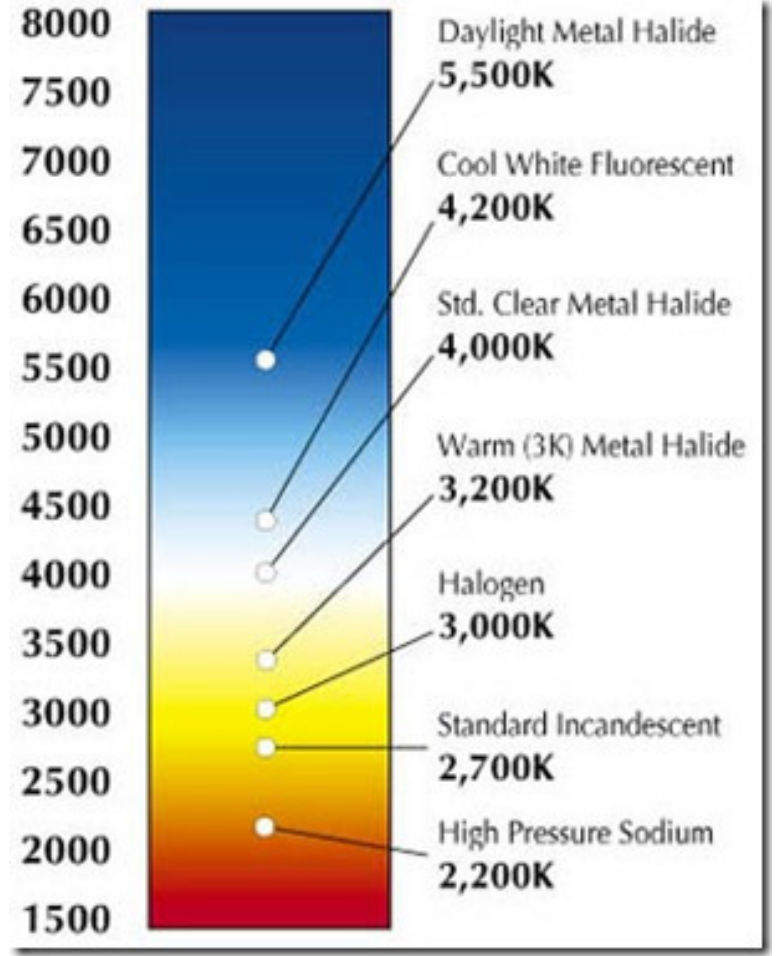

Figure 5 Colour Temperature Scheme (Source: www.google.com)

There are also light color temperature standards that must be met, in order to meet the needs of the function of the room. The color temperature of light also greatly affects the psychological impact of the user on the room, which can cause fatal problems. After applying several luminance standards, there is also a need to pay attention to the Color Suitability Index (CRI). The color match index is the ability of a light source to make color and the various color gradations of an object visible to the human eye. The color rendering index ranges from 0 to 100 and the higher the value indicates the better rendering capability. Color temperature differs from the color rendering index: color temperature characterizes the appearance of the color of a light source whereas the color rendering index shows how well the light represents the color of an object. However, to be able to compare the color rendering index ratings between two types of light sources, both sources must have the same color temperature. 


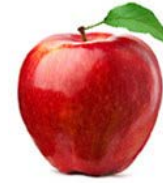

$2700 K$
CRI $9 ?$

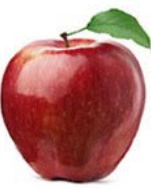

$2200 k$
CRI 90

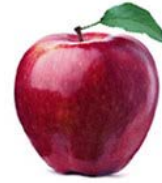

$2700 \mathrm{~K}$

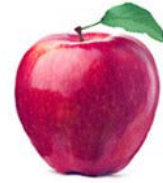

$2700 k$
CRI 70
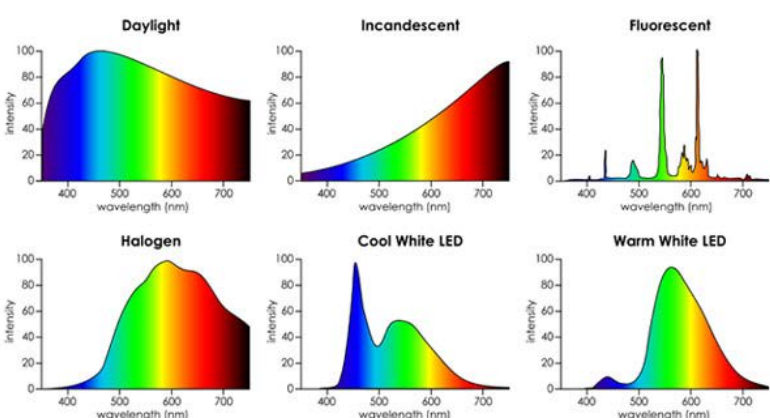

Figure 6 Colour Rendering Index (CRI)

(Source: www.google.com)

\subsection{Lighting Concept}

In designing lighting there are 3 lighting concepts that need to be considered, namely:

- Ambient lighting refers to the main lighting you use to illuminate the entire space. Generally, lighting is done by placing the lamp point at the center point of the room or at some point that is installed symmetrically and evenly.

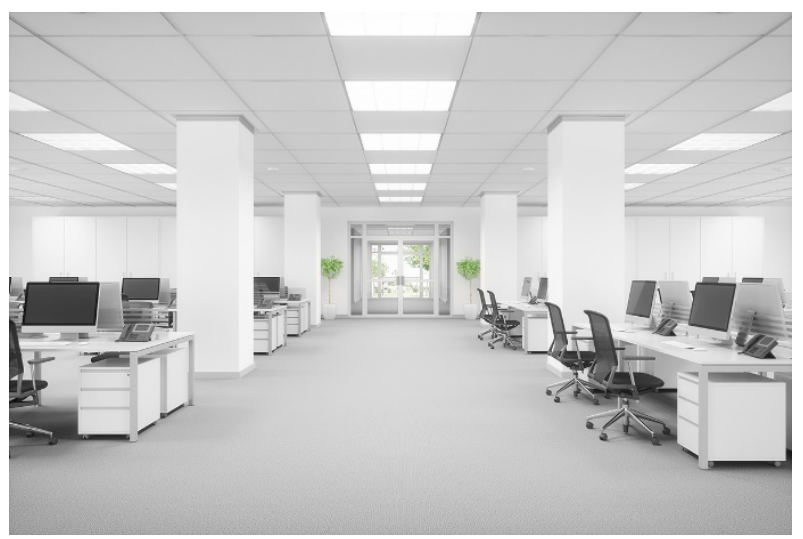

Figure 7 Ambient lighting

(Source: www.google.com)

- Focal Glow is lighting that functions as a light for certain objects (Accent), or as the main source of light (focal glow). Lighting with accents above the general ambience is good and appropriate will create a dynamic and exciting contrast of light in your room.

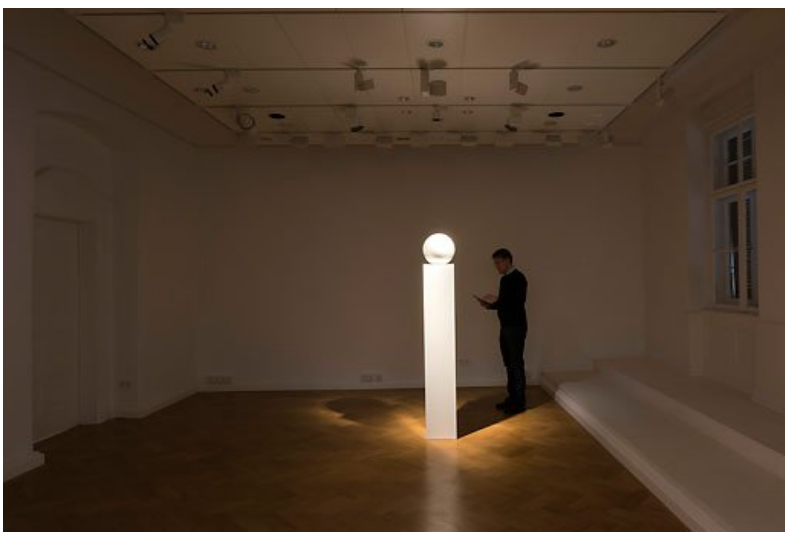

Figure 8 Focal glow lighting

(Source: www.google.com)

- Play of Brilliants is lighting that does present the impression of a game of light in the room. A game of light and sparkling sparkle over general ambience and accent/focal glow will create a whole lighting design.

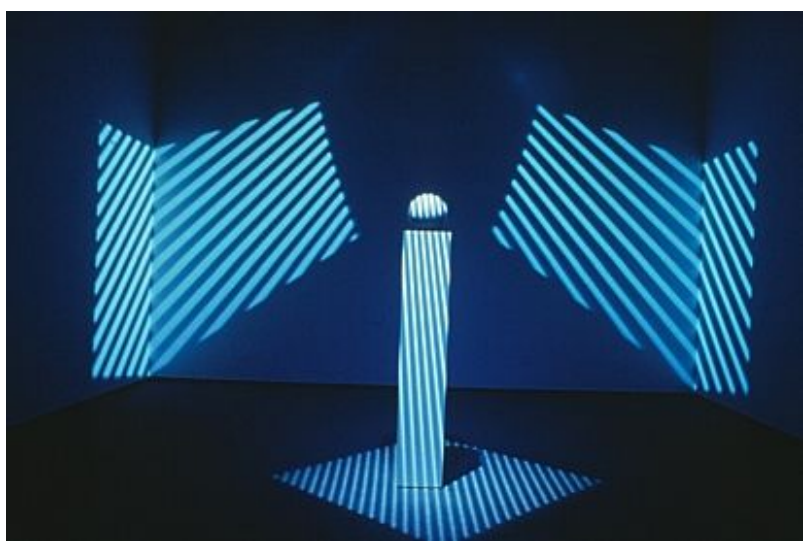

Figure 9 Play of brilliants lighting

(Source: www.google.com)

In the application of lighting concept, the intensity of light can be adjusted to the image of the room you want to build. As well as light intensity games can be done to create a space effect that is not flat/ bal.

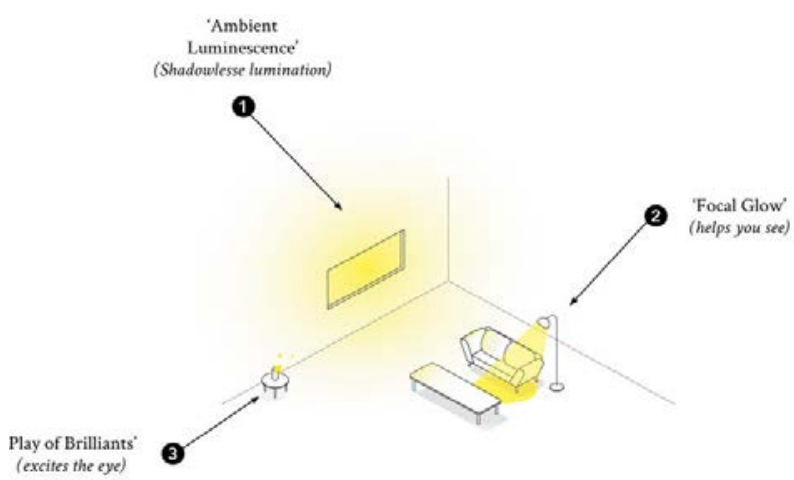

Figure 10 Illustration of Lighting Layering Concept (Source: www.google.com) 


\section{CONCLUSIONS}

In the current condition of Wayang Museum, especially in the field of lighting, experiencing some constraints, where the lighting design in the display area has not been maximal and has not fully met the needs of the room as a display room. Therefore, with this research can be drawn conclusions. There are several factors that must be considered in the concept of lighting to meet the needs of the display space function. There are Ambient Lighting, Focal Glow, and Play of Brilliants that must be applied to the interior display space. The selection of the right color temperature also greatly affects the lighting effect of the space as the image of the space. As well as the selection of the right light source so as not to damage museum collectibles.

\section{ACKNOWLEDGMENT}

In writing this journal is not separated from the help and support by the relevant parties, therefore I thank, Interior Design Program, Faculty of Art and Design, Tarumanagara University, who has provided the opportunity and time to conduct this research. To the family and friends who helped and supported the writing of this journal.

\section{REFERENCES}

[1] C. Dharmasetiawan, Teknik Pencahayaan dan Tata Letak Lampu, Jakarta: Grasindo, 1987.

[2] H. Frick, Ilmu Fisika Bangunan, Yogyakarta: Kanisius, 2003.

[3] E. Neufert, Architect Data, Jakarta: Erlangga, 1996.

[4] P. Suptandar, Aspek Pencahayaan Dalam Desain Interior, Jakarta, 1982.

[5] A. D, "Evaluasi Intensitas Pencahayaan (Illumination level) pada Perpustakaan Lingkungan Universitas Sriwijaya," Journal of Imdustrial Hygiene and Occupational Health, pp. Vol. 2, No. 1, Oktober 2017.

[6] W. H, "Analisis Pencahayaan Terhadap Kenyamanan Visual," Jurnal Arsitektur, Bangunan, \& Lingkungan Vol. 6, No. 2, pp. 65-70, Februari 2017. 